\title{
Biodegradation of plastics in soil and effects on nitrification activity. A laboratory approach
}

\section{Giulia Bettas Ardisson, Maurizio Tosin, Marco Barbale and Francesco Degli-Innocenti*}

Ecology of Products and Environmental Communication, Novamont S.p.A., Novara, Italy

\section{Edited by:}

Gavin Collins, National University of

Ireland, Ireland

\section{Reviewed by:}

Romy Chakraborty, Lawrence

Berkeley National Lab, USA

Bongkeun Song, Virginia Institute of

Marine Science, USA

\section{*Correspondence:}

Francesco Degli-Innocenti, Ecology of Products and Environmental

Communication, Novamont S.p.A.,

Via Fauser 8, 1-28100 Novara,

Italy

e-mail:fdi@novamont.com

The progressive application of new biodegradable plastics in agriculture calls for improved testing approaches to assure their environmental safety. Full biodegradation ( $\geq 90 \%$ ) prevents accumulation in soil, which is the first tier of testing. The application of specific ecotoxicity tests is the second tier of testing needed to show safety for the soil ecosystem. Soil microbial nitrification is widely used as a bioindicator for evaluating the impact of chemicals on soil but it is not applied for evaluating the impact of biodegradable plastics. In this work the International Standard test for biodegradation of plastics in soil (ISO 17556, 2012) was applied both to measure biodegradation and to prepare soil samples needed for a subsequent nitrification test based on another International Standard (ISO 14238, 2012). The plastic mulch film tested in this work showed full biodegradability and no inhibition of the nitrification potential of the soil in comparison with the controls. The laboratory approach suggested in this Technology Report enables (i) to follow the course of biodegradation, (ii) a strict control of variables and environmental conditions, (iii) the application of very high concentrations of test material (to maximize the possible effects). This testing approach could be taken into consideration in improved testing schemes aimed at defining the biodegradability of plastics in soil.

Keywords: bioplastics, biodegradation, biodegradability, soil ecotoxicity, soil nitrification, biodegradable materials, soil microbiology

\section{INTRODUCTION}

Plastic materials are used in several applications in modern agriculture. For example, plastic mulch films made with polyethylene are successfully applied to control weeds and stabilize soil temperature and moisture. In order to maintain the advantages conferred by using plastic products without having the burden of final waste management, plastic mulch films have been developed that are designed for biodegradation in soil and are used in place of traditional non-biodegradable mulch films. The intentional release of biodegradable plastics in soil implies that two aspects are satisfied: full biodegradability and no ecotoxic effects on soil organisms. Testing schemes and acceptability criteria based on these principles have already been developed: the "OK Biodegradable soil" Certification by the Belgian Institute Vinçotte; the French standard NF U 52001 (2005), the Italian standards UNI 11462 (2012), and UNI 11495 (2013).

The "OK Biodegradable soil" and the Italian standards set the biodegradation level to be reached in 2 years at $90 \%$, whereas the AFNOR standard has a more articulated testing scheme still based on the achievement of a biodegradation level equal to or greater than $90 \%$. The $90 \%$ biodegradation level is a very stringent requirement for showing plastics biodegradability. Aerobic biodegradation is the conversion of plastic material into carbon dioxide, water, and biomass (i.e., the new biological matter developed by the growing microorganisms) with the consumption of atmospheric oxygen:

$$
\mathrm{C}_{\text {plastic }}+\mathrm{O}_{2} \rightarrow \mathrm{CO}_{2}+\mathrm{H}_{2} \mathrm{O}+\mathrm{C}_{\text {residue }}+\mathrm{C}_{\text {biomass }}
$$

The test methods for measuring biodegradation are based on respirometry. Respirometric test methods can only assess one carbonic product of the reaction $\left(\mathrm{CO}_{2}\right)$. No reliable methods to determine the biomass $\left(\mathrm{C}_{\text {biomass }}\right)$ or the by-products $\left(\mathrm{C}_{\text {residue }}\right)$ produced during biodegradation are available yet. Therefore, the biomass and potential by-products are excluded from the equation, preventing a $100 \%$ mass balance being achieved. As a result, a complete biodegradation of " $\mathrm{C}_{\text {plastics" }}$ " will rarely lead to a complete mineralization (i.e., to a carbon dioxide evolution corresponding to the maximum amount expected in the event of total conversion of the "C $\mathrm{C}_{\text {plastics }}$ " into $\mathrm{CO}_{2}$ ) because at least part of the original plastic material will be converted into biomass as a result of anabolic biochemical pathways. For these reasons, a mineralization value equal to or greater than $90 \%$ is considered by the scientific community to be proof of complete biodegradation, not only in the field of biodegradable plastics but also in other sectors such as detergency.

The "OK Biodegradable soil" and the Italian and French standards also include ecotoxicity requirements. Ecotoxicity tests must be carried out in soil samples where plastic material added at $1 \%$ concentration has been degraded for 3 months. Ecotoxicity test methods currently applied by the standards are: the determination of seed germination and growth of plants (UNI 10780, 1998; ISO 11269-2, 2012); acute toxicity on earthworms (FD X 31-251, 1994; ISO 11268-1,2012); acute toxicity on aquatic organisms such as Daphnia (ISO 6341, 2012) or algae (NF T 90-375, 1998). Recently it has been suggested that microbial nitrification could also be included as a bioindicator to evaluate the impact of biodegradable polymers in soil (Chenon et al., 2012). 
Nitrification is important for the health of the soil and the ecosystem because it completes the mineralization of organic nitrogen started with the ammonification process, a relevant process in the nitrogen cycle. Ammonium is converted into nitrates by two consecutive steps performed by two groups of microorganisms: the ammonia-oxidizing bacteria $(\mathrm{AOB})$ and the ammonia-oxidizing archaea (AOA), that perform the first step of conversion of ammonium into nitrite $\left(\mathrm{NH}_{4}^{+} \rightarrow \mathrm{NO}_{2}^{-}\right)$and the nitrite-oxidizing bacteria (NOB), that perform the second step of oxidation of nitrites into nitrates $\left(\mathrm{NO}_{2}^{-} \rightarrow \mathrm{NO}_{3}^{-}\right.$; Xia et al., 2011). The nitrification inhibition test is widely used to monitor the effects of chemicals on soils (Pannu et al., 2012; Ruyters et al., 2013) because it is considered to be one of the most sensitive tests among the microbial exotoxicity assays (Reynolds et al., 1987; UBA, 1993; Ren and Frymier, 2003).

Even if widely applied in environmental toxicology, the nitrification test has never been applied for the evaluation of the effects of biodegradable plastics in soil under controlled laboratory conditions. In this context we are trying to increase the array of ecotoxicity tests applied in standard testing schemes in order to cover microorganisms besides plants and animals. For this purpose, we combine the test method for the evaluation of biodegradation of plastics in soil (ISO 17556, 2012) with the nitrification inhibition test (ISO 14238, 2012). First, biodegradation of mulch film is followed under controlled laboratory conditions and using high test material concentrations $(>1 \% \mathrm{w} / \mathrm{w})$; then, the resulting soil is tested for nitrification activity in order to verify possible effects of plastics biodegradation on soil health. The purpose of this approach is to determine the possible long-lasting effects of biodegradation of plastics on soil health. The assessment of the toxicity of plastics before biodegradation and the assessment of transient effects during biodegradation are out of the scope. For a discussion on the best conditions to perform eco-toxicity testing of biodegradable plastics see Degli-Innocenti (2014).

The applied test material loading in ISO 17556 (2012) is much higher than the expected application loading of biodegradable plastics in soil. For example: a typical biodegradable plastic film for mulching is $1.5 \times 10^{-5} \mathrm{~m}$ thick and has a density of $1,250 \mathrm{~kg} \mathrm{~m}^{-3}$. This means $1.88 \times 10^{-2} \mathrm{~kg} \mathrm{~m}^{-2}$ for one application. The soil depth where the plastic is typically used or remains after use is presumed to be $0.30 \mathrm{~m}$, in agreement with the normal depth of soil tillage. Therefore, $1 \mathrm{~m}^{2}$ of plastic film covering $1 \mathrm{~m}^{2}$ of soil surface will typically be mixed with a volume of soil equal to $0.3 \mathrm{~m}^{3}$. This amount of soil weighs approximately $450 \mathrm{~kg}$, considering a soil bulk density of $1500 \mathrm{~kg} \mathrm{~m}^{-3}$. Therefore, the typical loading of the plastic film in normal use will be approximately $0.0042 \%$ $\left(1.88 \times 10^{-2} \mathrm{~kg} / 450 \mathrm{~kg} \times 100\right)$.

\section{MATERIALS AND METHODS TEST MATERIAL}

The test material is a black mulch film made with Mater-Bi DF04P, a biodegradable plastic material based on corn starch and biodegradable copolyesters (Novamont). Before biodegradation testing the mulch film was powdered by means of cryogenic grinding with liquid nitrogen using an IKA M20 grinder. The elemental analysis of this film was $\mathrm{C}=61.00 \% \mathrm{~N}<0.1 \%$ and $\mathrm{H}=6.84 \%$ (analysis performed by Redox snc, Monza, Italy).

\section{REFERENCE MATERIAL}

The reference material was micro-crystalline cellulose (Merck) in powder, as prescribed by the standard test method ISO 17556 (2012). The elemental analysis was $\mathrm{C}=44.40 \% ; \mathrm{N}<0.1$; $\mathrm{H}=6.00 \%$ (analysis performed by Redox snc, Monza, Italy).

\section{BIODEGRADATION TEST}

The biodegradation test was carried out using the ISO 17556 (2012) test method. The test material is mixed with the selected soil. The mixture is allowed to stand in the test flask under controlled conditions over a period of time during which the carbon dioxide evolved is determined. In parallel, the background $\mathrm{CO}_{2}$ production is determined in a different flask containing soil without test material. The evolved carbon dioxide is determined at intervals by analyzing the carbon dioxide in air by an appropriate analytical method. The level of biodegradation expressed in per cent is determined by comparing the net carbon dioxide evolved with the theoretical amount (amount expected in case of total oxidation of the test material).

The soil was collected from an agricultural field at the Centro Sperimentazione ed Assistenza Agricola (CeRSAA) in Albenga (Italy). The soil is routinely analyzed by CeRSAA and has a C/N ratio of 9.2. The soil was screened with a $5 \mathrm{~mm}$ sieve.

The soil was then supplemented as described in Table 1, following the ISO 17556 (2012).

The total solids were determined after drying in an oven at $105^{\circ} \mathrm{C}$ until constant mass was achieved. The volatile solids were determined after calcination at $550^{\circ} \mathrm{C}$ until constant mass was achieved. The $\mathrm{pH}$ was determined by diluting the soil in distilled water. A $10 \mathrm{~g}$ sample of soil was mixed with $25 \mathrm{ml}$ of deionized water, stirred for $15 \mathrm{~min}$ and left unstirred for $30 \mathrm{~min}$ before measuring the $\mathrm{pH}$ with a Hanna Instruments $\mathrm{pHmeter}$ model $\mathrm{pH}$ 211 (Violante and Adamo, 2000).

According to ISO 17556 (2012), the $\mathrm{pH}$ of the inoculum should be between 6 and 8 and the $\mathrm{C} / \mathrm{N}$ ratio should be at least 40:1. Both conditions were met.

\section{BIODEGRADATION TEST APPARATUS}

The reactors are 3-L glass flasks. The temperature of the reactors is kept at $28^{\circ} \mathrm{C} \pm 2{ }^{\circ} \mathrm{C}$. Pressurized air is sent over a gas flow controller and an air flow rate of about $6 \mathrm{~L} / \mathrm{h}$ is supplied at the bottom

\section{Table 1 | Preparation of soil.}

\begin{tabular}{ll}
\hline Constituent & Grams \\
\hline Soil & 1000 \\
Mature compost screened $<5$ mm with & 40 \\
a $50 \%$ water content & \\
$\mathrm{KH}_{2} \mathrm{PO}_{4}$ & 0.2 \\
$\mathrm{MgSO}_{4}$ & 0.1 \\
$\mathrm{NaNO}_{3}$ & 0.4 \\
$\mathrm{Urea}$ & 0.2 \\
$\mathrm{NH}_{4} \mathrm{Cl}$ & 0.4 \\
$\mathrm{H}_{2} \mathrm{O}$ & $78 \mathrm{ml}$
\end{tabular}


of the reactors (dynamic conditions). The air flow and the $\mathrm{CO}_{2}$ concentration at each reactor outlet is automatically measured by means of an infra-red gas sensor (EC400 Eco-control Vimercate, Milan, Italy) and a mass flowmeter (Brooks Instruments, Model 5860S).

The $\mathrm{CO}_{2}$ evolution rate is calculated by multiplying the $\mathrm{CO}_{2}$ concentration $(\mathrm{g} / \mathrm{L})$ by the air flow rate $(\mathrm{L} / \mathrm{h})$. The amount of $\mathrm{CO}_{2}$ produced during two measurements is estimated by multiplying the $\mathrm{CO}_{2}$ evolution rate by the elapsed time from last measurement. The mineralization percentage is the ratio between the total net $\mathrm{CO}_{2}$ produced by the sample and the amount produced in the case of a complete transformation of its carbon into $\mathrm{CO}_{2}$.

\section{BIODEGRADATION TEST SET-UP}

A set of seven reactors was used. The test set-up is shown in Table 2.

\section{NITRIFICATION TEST}

The nitrification test was carried out using the ISO 14238 (2012) test method. The rates or extent of $\mathrm{N}$-mineralization in aerobic soils are determined by measuring the concentrations of ammonium, nitrite, and nitrate released during mineralization of an added nitrogenous organic compound. The influence of plastic biodegradation on $\mathrm{N}$-mineralization is determined by amending soil with a readily degradable source of organic nitrogen, and measuring the percentage inhibition of product formation in soil where plastics have been biodegraded as compared to an untreated control.

The soil samples used in this test derived from the biodegradation test (from Reactors R6, R13, and R15; see Table 2). After the biodegradation phase, soils are carefully crumbled and supplemented with $100 \mathrm{mg} / \mathrm{kg}$ dry soil of $\left(\mathrm{NH}_{4}\right)_{2} \mathrm{SO}_{4}$ in the form of powder. In practice $275.86 \mathrm{~g}$ of wet soil (water content $13 \%$ ) were carefully mixed with $112.8 \mathrm{mg}$ of $\left(\mathrm{NH}_{4}\right)_{2} \mathrm{SO}_{4}$. Soil sample is stored in the dark at room temperature for $12 \mathrm{~h}$ to let the salt grains dissolve into the soil and to reach a homogeneous concentration. After this period, subsamples of $15 \mathrm{~g}$ (dry mass) are withdrawn and each placed in a $100 \mathrm{ml}$ beaker; the beakers are then closed with Parafilm and incubated in the dark at $20^{\circ} \mathrm{C} \pm 2{ }^{\circ} \mathrm{C}$ until extraction. Once a week each sample is weighed in order to adjust water content to $13 \%$ and mixed to allow aeration of the soil.

Table 2 | Biodegradation test set-up.

\begin{tabular}{llll}
\hline $\begin{array}{l}\text { Reactor } \\
\text { No. }\end{array}$ & $\begin{array}{l}\text { Test or reference } \\
\text { material }\end{array}$ & $\begin{array}{l}\text { Mass of test or } \\
\text { reference } \\
\text { material } \mathbf{( g )}\end{array}$ & $\begin{array}{l}\text { Mass of } \\
\text { supplemented } \\
\text { soil (g) }\end{array}$ \\
\hline R 5 & Blank & 0 & 800.0 \\
R 6 & Blank & 0 & 800.0 \\
R 11 & Mater Bi DF04P & 10.0 & 800.0 \\
R 12 & Mater Bi DF04P & 10.0 & 800.0 \\
R 13 & Mater Bi DF04P & 10.0 & 800.0 \\
R 14 & Cellulose & 10.0 & 800.0 \\
R 15 & Cellulose & 10.0 & 800.0
\end{tabular}

At day 1, 8, 15, 22, and 29 after the addition of $\left(\mathrm{NH}_{4}\right)_{2} \mathrm{SO}_{4}$, extraction is performed by mixing one soil subsample (15 $\mathrm{g}$ as dry mass) with $75 \mathrm{ml}$ of a $1 \mathrm{M} \mathrm{KCl}$ solution in a $100 \mathrm{ml}$ beaker. The slurry is stirred for $1 \mathrm{~h}$ with a magnetic stirrer and then centrifuged at $6000 \mathrm{rpm}$ for $10 \mathrm{~min}$. The supernatant is collected, stored at $-20^{\circ} \mathrm{C}$ and sent for analyses.

The concentration of $\mathrm{NH}_{4}$, nitric-N, nitrous- $\mathrm{N}$, was analyzed by CHEMSERVICE S.r.l. (Novate Milanese, Milan, Italy) by using the standard methods of the Italian Water Research Institute (IRSA) and APAT [Agenzia per la Protezione dell'Ambiente e per i Servizi Tecnici; Istituto di Ricerca sulle Istituto di Ricerca sulle Acque (IRSA), 2014a]. In particular: $\mathrm{N}_{-} \mathrm{NH}_{4}$ with the Method 4030 A2- Ammonia Nitrogen, Spectrophotometric determination by means of Nessler reagent [Istituto di Ricerca sulle Acque (IRSA), 2014b], nitric nitrogen with the Method 4020 - Determination of anions (fluoride, chloride, nitrite, bromide, nitrate, phosphate, and sulfate) by ion chromatography [Istituto di Ricerca sulle Acque (IRSA), 2014c], nitrous nitrogen with the Method 4050 - Nitrous nitrogen [Istituto di Ricerca sulle Acque (IRSA), 2014d]. The expanded uncertainty of measurement was $\pm 15 \%$ and $\pm 4 \%$ for $\mathrm{N}-\mathrm{NO}_{3}$ and $\mathrm{N}-\mathrm{NH}_{4}$, respectively.

\section{STATISTICAL ANALYSIS}

The data were analyzed with Statgraphics Centurion XVI software (Statpoint Technologies, Inc. USA), by using the "comparison of regression lines" and the "Conditional Sums of Squares (ANOVA)" options.

\section{RESULTS}

\section{BIODEGRADATION}

The soil used in the biodegradation test had the following characteristics: total solids $=88.46 \% \pm 0.17$ (average of 3 determinations $\pm \mathrm{SD}$ ); volatile solids $=4.96 \% \pm 0.06$ (average of 3 determinations $\pm \mathrm{SD}) ; \mathrm{pH}=7.48$.

The total cumulative $\mathrm{CO}_{2}$ production for each reactor is shown in Figure 1. The different replicates showed a regular course and a very limited variance.

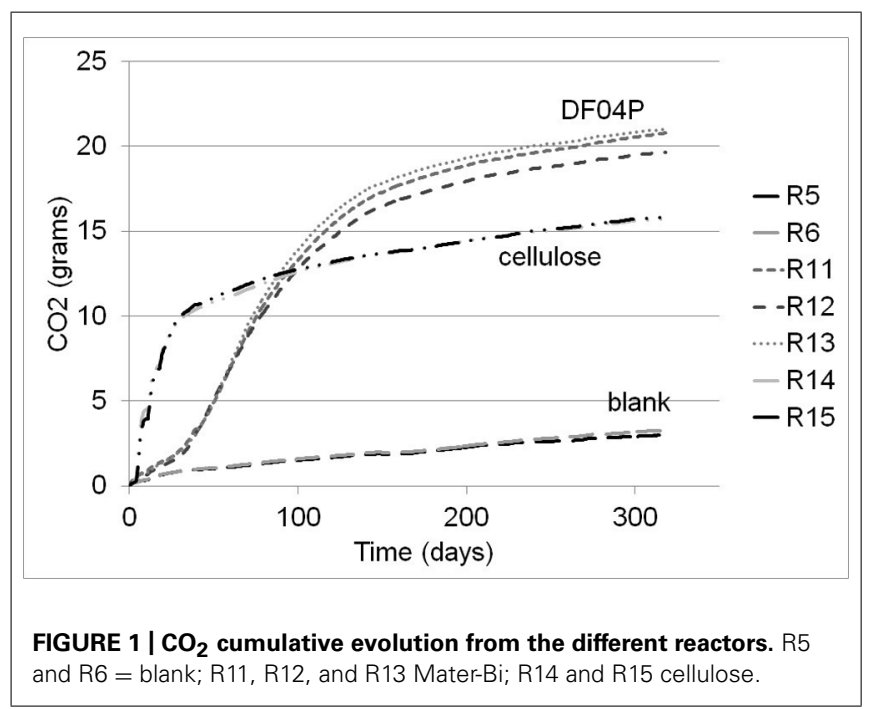




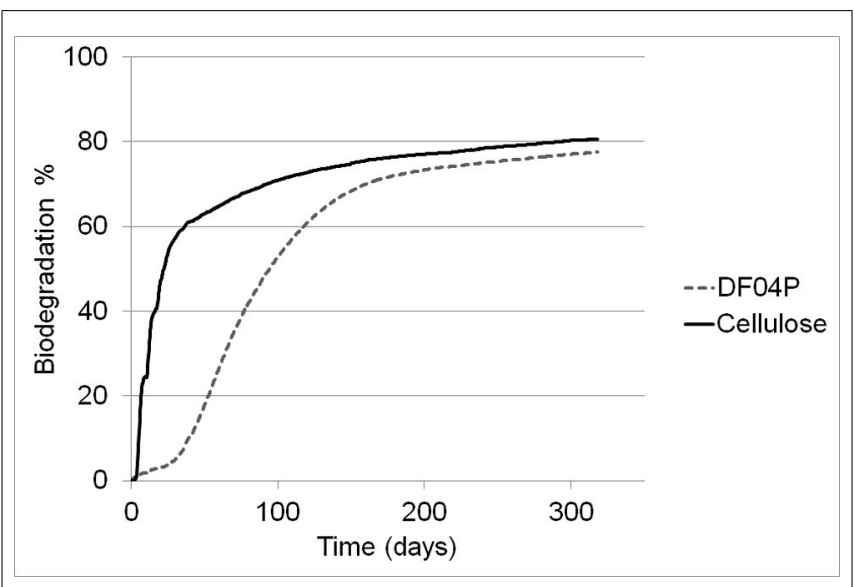

FIGURE 2 | Biodegradation of Mater-Bi DF04P (average of three replicates) and microcrystalline cellulose (average of two replicates).

The biodegradation percentage averages are plotted in Figure 2. Cellulose showed a very fast biodegradation phase that lasted about 50 days, followed by a progressive plateauing. Mater-Bi DF04P showed a lag phase of about 25 days followed by a steady biodegradation phase plateauing after 150 days. After 318 days, the biodegradation of both test material and reference material had reached a clear plateau. The single replicates of Mater-Bi had reached the following biodegradation percentages: $\mathrm{R} 11=78.88 \%$; $\mathrm{R} 12=73.74 \% ; \mathrm{R} 13=79.91 \%$. The single replicates of cellulose were $\mathrm{R} 14=80.16 \%$; R $15=80.92 \%$.

According to ISO 17556 (2012), the test is considered valid when: (a) the degree of biodegradation of the reference material is more than $60 \%$ at the plateau phase or at the end of the test; and (b) the amount of carbon dioxide evolved from the three blanks is within $20 \%$ of the mean at the plateau phase or at the end of the test. Cellulose reached the $60 \%$ biodegradation threshold after 38 days. For technical reasons, only two blank replicates were used; at the end of the tests the two replicates were comparable: 15.73 and $15.85 \mathrm{~g}$ of $\mathrm{CO}_{2}$. We therefore consider the test as valid.

After 318 days the $\mathrm{CO}_{2}$ measurements were discontinued. Reactor R6 (blank), R13 (Mater-Bi DF04P), and R15 (cellulose) were maintained for further testing. The $\mathrm{pH}$ of soils was: reactors $\mathrm{R} 6$ (blank) $=7.96$, R13 (Mater-Bi DF04P) $=8.29$, and R15 (cellulose $=8.15$. The soil samples were then stored in the dark at room temperature for 7 months without any further $\mathrm{CO}_{2}$ measurement. Three times per week the content was routinely mixed and wet with deionized water to keep the original water content and maintain aerobic conditions until the nitrification experiment.
Therefore, the biodegradation phase (both with and without $\mathrm{CO}_{2}$ monitoring) lasted 528 days in total.

The carbon balance of reactors R13 (Mater-Bi DF04P) and R15 (cellulose) is shown in Table 3. The residual carbon not mineralized into $\mathrm{CO}_{2}$ can be: (i) still bound in the original nonbiodegraded material $\left(\mathrm{C}_{\text {plastic }}\right)$, (ii) trapped in biomass $\left(\mathrm{C}_{\text {biomass }}\right)$, (iii) converted into some by-products $\left(\mathrm{C}_{\text {residue }}\right)$, as per Eq. (1).

\section{NITRIFICATION EXPERIMENT}

After the biodegradation phase, at the beginning of the nitrification test, the $\mathrm{pH}$ of blank, DF04F, and cellulose soils was 8.08, 8.18, and 8.03, respectively. The nitrification experiment was carried out as described in Materials and Methods and ran for 29 days. The $\mathrm{N}-\mathrm{NH}_{4}$ concentrations are plotted in Figure 3.

The amount of nitrogen added as ammonium was $100 \mathrm{mg} / \mathrm{kg}$ of dry soil. The ammonium was fast consumed in all three soils, returning to the original level in 15-22 days. A linear regression analysis was performed from day 1 to 15 for the Mater-Bi DF04P and from day 1 to 22 for the blank and cellulose (Table 4). The ammonium depletion rates of the three soils differ significantly: Mater-Bi DF04P > blank soil > cellulose soil. The regression analysis and the applied statistical test indicated that there are statistically significant differences among the slopes for the various values of soil type at the $95 \%$ confidence level.

The depletion of ammonium was accompanied by the appearance of nitrate. The nitrate measurements turned out to be quite

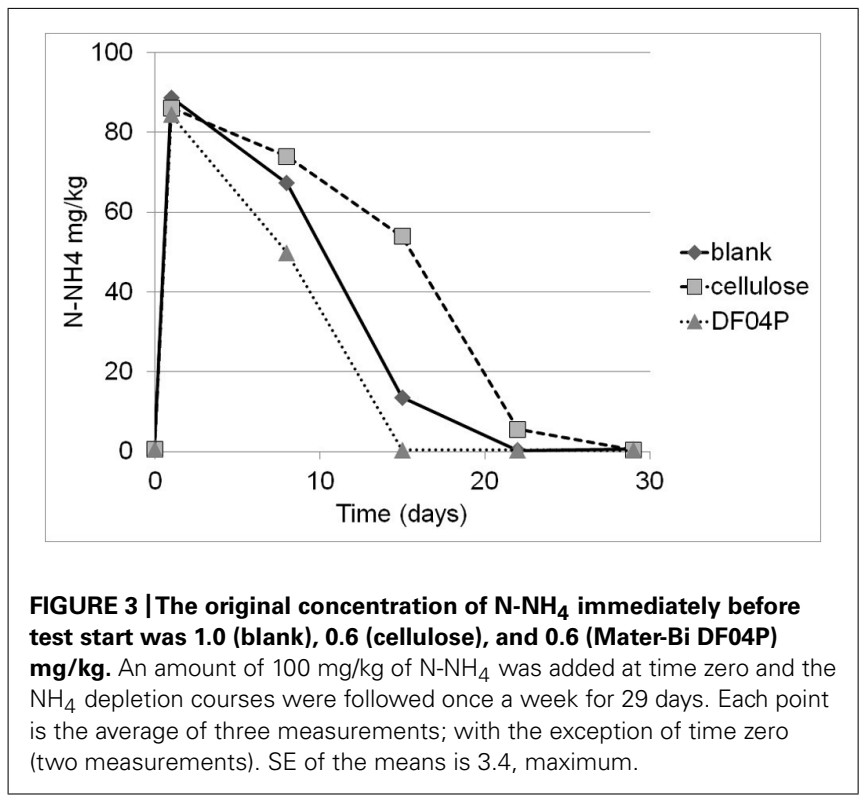

Table 3 | Carbon balance of reactors R13 and R15.

\begin{tabular}{lllllll}
\hline Reactor & Material & $\begin{array}{l}\text { Amount g per } \\
\text { reactor }\end{array}$ & $\begin{array}{l}\text { Carbon content } \\
\%\end{array}$ & $\begin{array}{l}\text { Carbon available for } \\
\text { biodegradation } \mathbf{g} \\
\text { per reactor }\end{array}$ & $\begin{array}{l}\text { Mineralization \% } \\
\text { Carbon converted } \\
\text { into } \mathbf{C O}_{\mathbf{2}} \mathbf{g}\end{array}$ \\
\hline R15 & Cellulose & 10.0 & 44.4 & 4.44 & 80.93 & 3.59 \\
R13 & Mater-Bi DF05P & 10.0 & 61.0 & 6.10 & 79.91 & 4.87 \\
carbon $\mathbf{g}$
\end{tabular}


Table 4 | Linear regression analysis of ammonium depletion courses.

\begin{tabular}{llll}
\hline Soil type & Intercept & Slope $\left(\mathbf{m g ~ N ~ k g}^{-\mathbf{1}} \mathbf{d}^{-\mathbf{1}}\right)$ & $\mathbf{R}^{\mathbf{2}}$ \\
\hline Mater Bi DF04P & 92.8 & -6.0 & 0.97 \\
Blank & 94.8 & -4.5 & 0.93 \\
Cellulose & 97.7 & -3.7 & 0.85 \\
\hline
\end{tabular}

variable (Figure 4) as a consequence of the higher expanded uncertainty of the $\mathrm{N}-\mathrm{NO}_{3}$ measurement (see Materials and Methods). The result of a linear regression analysis is shown in Table 5.

The regression analysis and the applied statistical tests (see Materials and Methods) indicate that there is a statistically significant relationship between the $\mathrm{N}-\mathrm{NO}_{3}$ concentration and the time at the $95.0 \%$ confidence level. Differences among the slopes $(\mathrm{N}$ $\mathrm{NO}_{3}$ formation rates) are not significant while differences among the intercepts are significant (at the 95\% confidence level).

Considering the difference between the $\mathrm{N}-\mathrm{NO}_{3}$ concentrations estimated at time 0 and time 29 (see Table 6), 102.2, 124.6, and $83.8 \mathrm{mg} / \mathrm{kg}$ of new $\mathrm{N}-\mathrm{NO}_{3}$ was formed in Mater-Bi DF04P soil, blank soil, and cellulose soil, respectively.

No N-NO $\mathrm{N}_{2}$ was detected in any sample with the exception of a spike of $8.5 \mathrm{mg} / \mathrm{kg}$ in the Mater-Bi DF04P sample at day 8 .

\section{DISCUSSION}

A mulch film made with Mater-Bi DF04P was tested for biodegradation using the standard test method ISO 17556 (2012). This

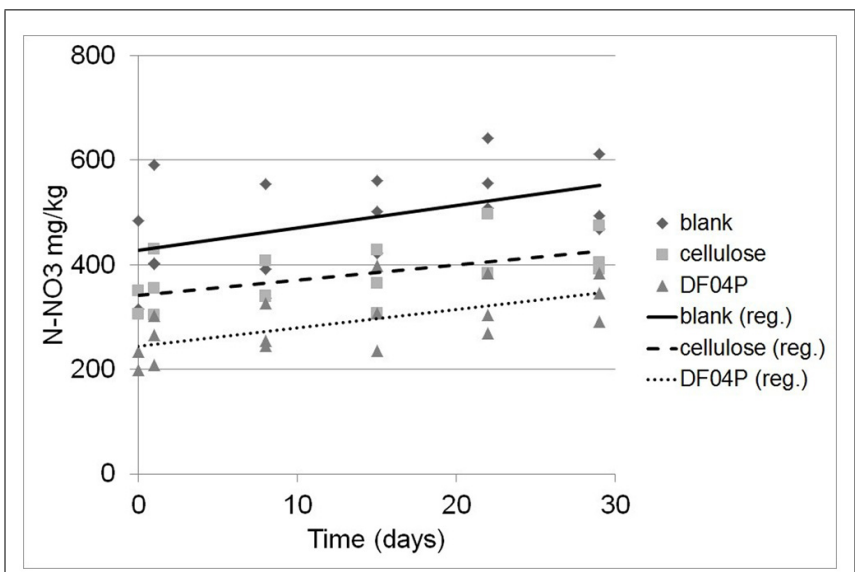

FIGURE 4 | Determination of $\mathrm{N}-\mathrm{NO}_{3}$ concentration at different times after $\mathrm{NH}_{4}$ addition and the corresponding regression lines.

Table 5 | Linear regression analysis of $\mathrm{NO}_{3}$ formation courses.

\begin{tabular}{llll}
\hline Soil type & Intercept & Slope $\left(\mathbf{m g ~ N ~} \mathbf{~ g ~}^{-\mathbf{1}} \mathbf{d}^{\mathbf{- 1}}\right)$ & $\boldsymbol{R}^{\mathbf{2}}$ \\
\hline DF04P & 244.4 & 3.52 & 0.389 \\
Blank & 427.9 & 4.29 & 0.236 \\
Cellulose & 342.1 & 2.88 & 0.307
\end{tabular}

Table 6 | The predicted values for $\mathrm{N}-\mathrm{NO}_{3}$ using the regression analysis are shown with the $95.0 \%$ confidence intervals.

\begin{tabular}{lllll}
\hline \multirow{2}{*}{$\begin{array}{l}\text { Time } \\
\text { (days) }\end{array}$} & Soil type & $\begin{array}{l}\text { Predicted } \\
\mathbf{N}^{-N^{3}} \mathbf{~ ( m g / k g )}\end{array}$ & \multicolumn{2}{c}{$\mathbf{9 5 . 0 0 \%}$ Confidence limits } \\
\cline { 4 - 5 } & & & Lower & Upper \\
\hline 0 & DF04P & 244.4 & 194.2 & 294.6 \\
0 & Blank & 427.9 & 377.7 & 478.0 \\
0 & Cellulose & 342.1 & 291.9 & 392.3 \\
29 & DF04P & 346.6 & 290.3 & 402.9 \\
29 & Blank & 552.5 & 496.2 & 608.8 \\
29 & Cellulose & 425.9 & 369.6 & 482.2
\end{tabular}

test method requires a high initial dose of test material, that is, at least 100 times higher than the concentration applied to agricultural soil under the normal usage of mulch film. This makes ISO 17556 (2012) also suitable to prepare samples for ecotoxicity testing, where high concentrations of test material are desired in order to maximize the chance of detecting possible negative effects. Biodegradation of Mater-Bi DF04P and cellulose (used as the positive reference) reached a plateau phase after about 200 days (Figure 2 ) and biodegradation rates were negligible at day 318 , when it was decided to discontinue the $\mathrm{CO}_{2}$ measurements, because a test elongation would not have added more information. Three reactors, one for each experimental group (cellulose, DF04P, and blank) were not discarded but maintained under constant environmental conditions (humidity and aeration) for a further 7 months without any $\mathrm{CO}_{2}$ measurement, until the nitrification test. Therefore, the biodegradation phase of the samples subjected to the nitrification test lasted 528 days in total, within the maximum time prescribed by the standards for soil biodegradability (2 years maximum).

The mulch film showed high levels of mineralization in soil. The biodegradation relative to cellulose was $96.24 \%$ after 318 days. This is considered as proof of soil biodegradability by the Vinçotte "OK Biodegradable Soil” testing scheme and also by French standard NF U 52-001 (2005) and by Italian standards UNI 11462 (2012) and UNI 11495 (2013).

After the biodegradation phase, the different soils were tested for the nitrification ability considered to be a relevant parameter for monitoring soil quality. The nitrification test procedure derived from the International Standard ISO 14238 (2012). The results showed that the soil where the mulch film had been biodegraded did not inhibit nitrification in comparison with blank soil and soil where cellulose (a GRAS, Generally Recognized As Safe, substance) had degraded in parallel.

The ammonium depletion was total in all soils and the depletion rate in soil that had been supplemented with the biodegradable mulch film was even higher. The ammonium depletion can be caused by nitrification, microbial uptake, and loss. The ammonium depletion was accompanied by the appearance of newly formed $\mathrm{NO}_{3}$. A quite high dispersion of the $\mathrm{NO}_{3}$ values was found (Figure 4). This data scattering is due to the rather high expanded uncertainty of the $\mathrm{N}-\mathrm{NO}_{3}$ measurement. This variability seems 
to be common in this kind of study (Ruyters et al., 2013) and must be addressed with a statistical approach. The experimental set up suggested by the International standard ISO 14238 (2012) was designed to prevent the establishment of anoxic conditions that would lead to denitrification. We do not have data to exclude that the observed variation of $\mathrm{N}-\mathrm{NO}_{3}$ measurements was due to denitrification caused by the establishment of anoxic micro-environments within the soil samples.

$\mathrm{NO}_{2}$ was only detected in very small amounts in the Mater-Bi soil as a spike after 8 days of incubation. At the same time the oxidation of ammonium was at its culmination as shown in Figure 3. We consider this to be an indication that the first step $\left(\mathrm{NH}_{4}^{+} \rightarrow \mathrm{NO}_{2}^{-}\right)$ carried out by $\mathrm{AOB}$ is temporarily slightly faster than the second step $\left(\mathrm{NO}_{2}^{-} \rightarrow \mathrm{NO}_{3}^{-}\right)$performed by nitrate-oxidizing bacteria (NOB).

The amount of newly formed $\mathrm{N}-\mathrm{NO}_{3}$ is fairly consistent with the amount of $\mathrm{N}-\mathrm{NH}_{4}$ added to the soils, suggesting that the added $\mathrm{N}-\mathrm{NH}_{4}$ was indeed quantitatively converted into $\mathrm{N}-\mathrm{NO}_{3}$ by means of nitrification.

No statistically significant differences were noticed in the $\mathrm{NO}_{3}$ formation rate among the three soils. This suggests that the soil nitrification activity was not affected by the biodegradation of the plastic mulch film.

On the other hand, the intercepts (i.e., the original $\mathrm{NO}_{3}$ concentration of the soils at time 0 ) are different. The $\mathrm{NO}_{3}$ concentration at the beginning of the nitrification experiment was higher in the blank soil and lower in the cellulose soil and even more so in the DF04P soil (see Figure 4; Table 6). This result at first glance is unexpected because the three soils derived from the same source, i.e., a well homogenized soil sample, distributed into the different reactors at the beginning of the biodegradation phase. Thus an identical $\mathrm{NO}_{3}$ concentration was also expected after 528 days. In order to explain these differences we make the hypothesis that $\mathrm{NO}_{3}$ was assimilated by microorganisms during the biodegradation phase and trapped in biomass. The addition of a biodegradable carbon source in a soil elicits microbial growth with formation of new biomass. As a consequence, also uptake and assimilation of $\mathrm{NO}_{3}$ are stimulated in order to cope with the biosynthesis of nitrogen compounds (e.g., amino acids, nucleosides). We can estimate the amount of $\mathrm{NO}_{3}$ needed for the biosynthesis of new biomass with some calculations based on the following assumptions. The first assumption is that all the residual carbon (Table 3) not mineralized into $\mathrm{CO}_{2}$ has been assimilated and used for the microbial anabolism. The second assumption is that $1 \mathrm{~g}$ of nitrogen is needed for $10 \mathrm{~g}$ of carbon assimilated into biomass, considering that the typical carbon/nitrogen ratio of microbial biomass is 10:1 (Pirt, 1975). The carbon of cellulose assimilated in biomass was $0.85 \mathrm{~g}$ (see Table 3). Applying the 1:10 ratio, $0.085 \mathrm{mg}$ of nitrogen can be expected to be taken up from soil and assimilated together with this carbon. This amount corresponds to a concentration of $105.8 \mathrm{mg} / \mathrm{kg}$ of $\mathrm{N}-\mathrm{NO}_{3}$ ( $85 \mathrm{mg}$ in $800 \mathrm{~g}$ of soil; see Table 2). Subtracting this amount from the $\mathrm{N}-\mathrm{NO}_{3}$ concentration of blank soil ( $428 \mathrm{mg} / \mathrm{kg})$, an amount of $322 \mathrm{mg} / \mathrm{kg}$ is left, very similar to the concentration actually measured in cellulose soil after the biodegradation phase $(342 \mathrm{mg} / \mathrm{kg})$. Similarly, a theoretical concentration of $274 \mathrm{mg} / \mathrm{kg}$ of $\mathrm{N}-\mathrm{NO}_{3}$, consistent with the experimental measurement $(244 \mathrm{mg} / \mathrm{kg})$, is found for Mater-Bi
DF04P. There is good consistency between the N-NO 3 concentration estimated by applying the hypothetical assumptions and the experimental values. This supports the hypothesis that the $\mathrm{NO}_{3}$ deficiency found in soils supplemented with a biodegradable carbon source in comparison with the blank soil is indeed the consequence of nitrogen assimilation caused by microbial growth and biomass formation. This indirectly also supports the idea that the residual, non-mineralized carbon is indeed converted into biomass.

To our knowledge, the present study is the first attempt to set up a laboratory approach based on the combination of two standard test methods: the biodegradation test (ISO 17556, 2012) for the measurement of biodegradation and the preparation of soil samples under controlled conditions and the ISO 14238 (2012) for the measurement of nitrification activity. The results of this work suggest that the addition of biodegradable plastics does not exert an inhibitory effect on the nitrification activity of soil even when the applied dose is 100 times higher than the normal concentration. The nitrifying capability of soil after biodegradation of such a high amount of biodegradable mass is not impaired. The absence of negative effects of MaterBi mulch film on soil nitrification capability is not unexpected considering that Mater-Bi biodegradable plastics: (i) are not toxic (for example the Acute Oral Toxicity of Mater-Bi in rats is $\mathrm{DL}_{50}>2000 \mathrm{mg} / \mathrm{kg}$ (OECD 420, 2001), (ii) are composed of biodegradable monomers (Siotto et al., 2011, 2012), and (iii) tend to be either in a solid inert form (before degradation) or, after enzymatic depolymerization, tend to be rapidly mineralized (Saponaro et al., 2008).

Effects on the nitrification activity of soils mulched with bioplastics were reported by Chenon etal. (2012). However, the experiments were carried out on soil samples taken from not fully characterized fields where biodegradable mulches had been applied. Field testing requires an extended experimental design and a methodological and statistical approach similar to that applied in agronomical studies in order to cope with the many environmental factors that can undermine the establishment of a credible cause-effect relationship. The laboratory approach described in this Technology Report drastically reduces the uncertainty by imposing strictly controlled conditions.

\section{CONCLUSION}

The aim of this study was to monitor mulch film biodegradation, to prepare soil samples for nitrification tests under laboratory controlled conditions and to apply the nitrification test after substantial biodegradation of the test material and in any case within the 2-year testing period prescribed by the standards.

We consider the test approach applied in this work to be suitable for reaching conclusions on the effects of biodegradable plastics on soil for the following reasons:

(1) A unique, well homogenized soil is either mixed with the test material or used as blank; the soils are then treated in parallel, the only difference being the test material. The effects, if any, cannot be reasonably ascribed to poor sampling design or other uncontrolled factors. 
(2) The test materials are well characterized and added by the practitioner under controlled conditions.

(3) Doses are set by the practitioner. Very high concentrations can be tested in order to be able to detect even very mild effects.

(4) Test conditions are well controlled.

(5) Substances released during biodegradation cannot be lost by leaching because the system is closed and hence any solid or liquid substance formed during biodegradation is either degraded or it builds up in the test system. If any substance that could affect soil activity were produced, this would be detected on the basis of test sensitivity.

The test approach applied in this work seems suitable for the application in the sector of biodegradable plastics but it needs to be replicated with other plastic materials and other soils in order to be validated.

\section{ACKNOWLEDGMENTS}

The research leading to this work has received funding from the European Union Seventh Frame-work Programme for Research and Technological Development (FP7/2007-2013) via the project "Open-Bio: Opening bio-based markets via standards, labelling and procurement" under grant agreement no. KBBE/FP7EN/613677. Many thanks to Raffaella Stracquadanio for helping in manuscript preparation.

\section{REFERENCES}

Chenon, P., Badin, A.-L., Nassr, N., Kremer, L., and Thevenin, N. (2012). "Ecotoxicological impacts of biodegradable polymers in agricultural soils," in Proceedings of the ORBIT 2012 Conference, June 2012, Rennes.

Degli-Innocenti, F. (2014). Biodegradation of plastics and ecotoxicity testing: when should it be done. Front. Microbiol. 5:475. doi: 10.3389/fmicb.2014. 00475

FD X 31-251. (1994). Qualité du Sol-Effets des Polluants vis à vis des Vers de Terre (Eisenia fetida)_Partie 1: Détermination de la Toxicité Aiguë en Utilisant des Substrats de Sol Artificiel.

ISO 6341. (2012). Water Quality - Determination of the Inhibition of the Mobility of Daphnia magna Straus (Cladocera, Crustacea) - Acute Toxicity Test.

ISO 11268-1. (2012). Soil Quality - Effects of Pollutants on Earthworms - Part 1: Determination of Acute Toxicity to Eisenia fetida/Eisenia Andrei.

ISO 11269-2. (2012). Soil Quality - Determination of the Effects of Pollutants on Soil Flora-Part 2: Effects of Contaminated Soil on the Emergence and Early Growth of Higher Plants.

ISO 14238. (2012). Soil Quality - Biological Methods - Determination of Nitrogen Mineralization and Nitrification in Soils and the Influence of Chemicals on these Processes.

ISO 17556. (2012). Plastics - Determination of the Ultimate Aerobic Biodegradability of Plastic Materials in Soil by Measuring the Oxygen Demand in a Respirometer or the Amount of Carbon dioxide Evolved.

Istituto di Ricerca sulle Acque (IRSA). (2014a). Home Page. Available at: http://www.irsa.cnr.it/ShPage.php?lang=en\&pag=home [accessed October 2, 2014].

Istituto di Ricerca sulle Acque (IRSA). (2014b). Metodo 4030 Azoto Ammoniacale. Available at: http://www.irsa.cnr.it/Docs/Capitoli/4030.pdf [accessed October 2, 2014].

Istituto di Ricerca sulle Acque (IRSA). (2014c). Metodo 4020 Determinazione di Anioni (Fluoruro, Cloruro, Nitrito, Bromuro, Nitrato, Fosfato e Solfato) Mediante Cromatografia Ionica. Available at: http://www.irsa.cnr.it/Docs/Capitoli/4020.pdf [accessed October 2, 2014].
Istituto di Ricerca sulle Acque (IRSA). (2014d). Metodo 4050 Azoto Nitroso. Available at: http://www.irsa.cnr.it/Docs/Capitoli/4050.pdf [accessed October 2, 2014].

NF T 90-375. (1998). Qualité de L'eau - Détermination de la Toxicité Chronique des Eaux par Inhibition de la Croissance de L'algue D'eau Douce Pseudokirchneriella subcapitata (Selenastrum capricornutum).

NF U 52-001. (2005). Biodegradable Mulching Film: Test Methods and Criteria.

OECD 420. (2001). Guideline for Testing of Chemicals. Acute Oral Toxicity - Fixed Dose Procedure.

Pannu, M. W., O'Connor, G. A., and Toor, G. S. (2012). Toxicity and bioaccumulation of biosolids-borne triclosan in terrestrial organisms. Environ. Toxicol. Chem. 31, 646-653. doi: 10.1002/etc.1721

Pirt, S. J. (1975). Principles of Microbe and Cell Cultivation. Oxford: Blackwell Scientific Publications.

Ren, S., and Frymier, P. D. (2003). Use of multidimensional scaling in the selection of wastewater toxicity test battery components. Wat. Res. 37, 1655-1661. doi: 10.1016/S0043-1354(02)00518-3

Reynolds, L., Blok, J., de Morsier, A., Gerike, P., Wellens, H., and Bontinck, W. J. (1987). Evaluation of the toxicity of substances to be assessed for biodegradability. Chemosphere 16, 2259-2277. doi: 10.1016/0045-6535(87)90284-0

Ruyters, S., Salaets, P., Oorts, K., and Smolders, E. (2013). Copper toxicity in soils under established vineyards in Europe: a survey. Sci. Total Environ. 443, 470-477. doi: 10.1016/j.scitotenv.2012.11.001

Saponaro, S., Sezenna, E., Degli-Innocenti, F., Mezzanotte, V., and Bonomo, L. (2008). A screening model for fate and transport of biodegradable polyesters in soil. J. Environ. Manage. 88, 1078-1087. doi: 10.1016/j.jenvman.2007. 05.010

Siotto, M., Sezenna, E., Saponaro, S., Degli-Innocenti, F., Tosin, M., Bonomo, L., et al. (2012). Kinetics of monomer biodegradation in soil. J. Environ. Manage. 93, 31-37. doi: 10.1016/j.jenvman.2011.08.018

Siotto, M., Tosin, M., Degli-Innocenti, F., and Mezzanotte, V. (2011). Mineralization of monomeric components of biodegradable plastics in preconditioned and enriched sandy loam soil under laboratory conditions. Water Air Soil Pollut. 221, 245-254. doi: 10.1007/s11270-011-0787-8

UBA. (1993). Entwurf zur Bewertung von Bodenbelastungen, Fachgebiet I 3.7. Berlin: Umweltbundesamt.

UNI 10780. (1998). Compost-Classificazione, Requisiti e Modalità di Impiego.

UNI 11462. (2012). Materiali Plastici Biodegradabili in Suolo - Tipi, Requisiti e Metodi di Prova.

UNI 11495. (2013). Materiali Termoplastici Biodegradabili per Uso in Agricoltura e Orticoltura - Film per Pacciamatura - Requisiti e Metodi di Prova.

Violante, P., and Adamo, P. (2000). “II. Reazione," in Metodi di Nalisi Chimica del Suolo, ed. P. Violante (Milano: Franco Angeli), 1-13.

Xia, W., Zhang, C., Zeng, X., Feng, Y., Weng, J., Lin, X., et al. (2011). Autotrophic growth of nitrifying community in an agricultural soil. ISME J. 5, 1226-1236. doi: 10.1038/ismej.2011.5

Conflict of Interest Statement: The authors declare that the research was conducted in the absence of any commercial or financial relationships that could be construed as a potential conflict of interest.

Received: 11 July 2014; accepted: 28 November 2014; published online: 15 December 2014.

Citation: Bettas Ardisson G, Tosin M, Barbale $M$ and Degli-Innocenti F (2014)

Biodegradation of plastics in soil and effects on nitrification activity. A laboratory approach. Front. Microbiol. 5:710. doi: 10.3389/fmicb.2014.00710

This article was submitted to Microbiotechnology, Ecotoxicology and Bioremediation, a section of the journal Frontiers in Microbiology.

Copyright (c) 2014 Bettas Ardisson, Tosin, Barbale and Degli-Innocenti. This is an openaccess article distributed under the terms of the Creative Commons Attribution License (CC BY). The use, distribution or reproduction in other forums is permitted, provided the original author(s) or licensor are credited and that the original publication in this journal is cited, in accordance with accepted academic practice. No use, distribution or reproduction is permitted which does not comply with these terms. 